\title{
JUURNAL.RU
}

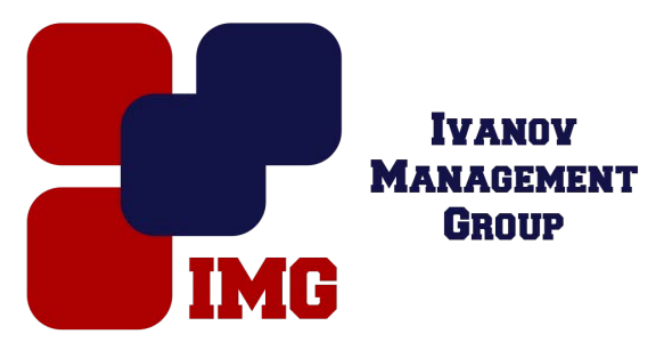

Простынюк Т. В., Миронов В.В., Сагандыков С.3. Омский государственный аграрный университет имени П.А. Столыпина Омск, Россия

doi: 10.18411/lj-31-10-2016-3-10

idsp 000001:lj-31-10-2016-3-10

\section{Влияния жидкой фракции свиного навоза на урожайность и качество зерна пшеницы яровой при возделывании на лугово-черноземной почве Омской области}

\section{Аннотация}

В статье затрагивается тема влияния жидкой фракции свиного навоза на урожайность и качество зерна пшеницы яровой в Омской области. Обычно свиной навоз используется для удобрения овощных культур, т.к. зерновые культуры отличаются невысоким выносом биогенных элементов, и соответственно, данное исследование в условиях Западной Сибири изучается впервые.

Ключевые слова: свиной навоз, урожайность, пшеница яровая, незаменимые аминокислоты, заменимые аминокислоты, протеин, клетчатка.

Навоз - органическое удобрение, самое известное и применяемое во всех странах мира, на протяжении всей истории мирового земледелия. Этот вид органики является естественным источником макроэлементов - азота, фосфора и калия, а также целого ряда микроэлементов, таких, как известь, магнезия, сера, хлор и кремний, необходимых для полноценной жизнедеятельности растений.

Свиной навоз как удобрение очень недооценен в наших краях, хотя в нем содержится больше органики, фосфора и азота в форме, доступной для растений, чем в навозе КРС $[1,2]$.

В настоящее время перед производителем стоит проблема повышения урожайности. Эту проблему можно решить путем внесения органических 
удобрений, которые повышают плодородие почвы и тем самым могут увеличить урожайность культуры и улучшить её качество.

Обычно свиной навоз используется для удобрения овощных культур, т.к. зерновые культуры отличаются невысоким выносом биогенных элементов. Соответственно, данное исследование в условиях Западной Сибири изучается впервые. В этом и состоит научная новизна работы $[3,4]$.

Задачи исследования:

- определить влияние жидкой фракции свиного навоза

- на урожайность,

- на качество зерна пшеницы яровой.

Опыт был заложен в производственных условиях на лугово- черноземной почве комплекса ООО «РУССКОМ-Агро» Омской области Кормиловского района.

Нами был изучено влияние жидкой фракции свиного навоза на урожайность пшеницы яровой (таблица 1).

Таблица 1

Урожайность пшенищьы яровой при внесении жидкой фракичии свиного навоза

\begin{tabular}{|c|c|c|c|}
\hline \multirow{2}{*}{ Доза, т/га } & \multirow{2}{*}{ Урожайность, т/га } & \multicolumn{2}{|c|}{ Прибавка } \\
\cline { 3 - 4 } & & т/га & \multirow{2}{*}{} \\
\cline { 3 - 4 } & 3,50 & - & 12,9 \\
\hline 0 & 3,95 & 0,45 & 23,4 \\
\hline 50 & 4,32 & 0,82 & 35,7 \\
\hline 100 & 4,75 & 1,25 & 42,0 \\
\hline 200 & 4,97 & 1,47 & 34,0 \\
\hline 250 & 4,69 & 1,19 & \\
\hline
\end{tabular}

На контрольном варианте урожайность составила 3,5 т/га. При внесении 50 т/га свиного навоза урожайность составила 3,95 т/га, что на 0,45 т/га (12,9\%) больше, чем в контрольном варианте. В зависимости от дозы внесения свиного навоза прибавка по сравнению с контрольным вариантом варьируется от 0,45 до 1,47 т/га, что составляет 12,9 - $42 \%$. При внесении 200 т/га жидкой фракции свиного навоза получена самая высокая урожайность по опыту - 4,97 т/га, что на 1,47 т/га или 42,0 \% больше, чем в контрольном варианте. При внесении большей дозы навоза отмечено снижение урожайности.

Результаты нашего исследования показали, что внесение различных доз жидкой фракции свиного навоза неоднозначно повлияли на качество зерна пшеницы яровой. 
Протеин пшеницы представлен в основном двумя белками - проламином (глиадином) и глютелином (глютенином), смесь которых называют глютеном (клейковиной). В хлебопекарной промышленности используют пшеницу с большим содержанием клейковины, а при использовании зерна на кормовые цели, содержание клейковины в зерне должно быть не высоким. Минимальное содержание клейковины отмечено на варианте с внесением 50 т/га свиного навоза в зерне (рис.1).

Пшеница нуждается в азоте для выработки протеина. Так как протеин составляет внутреннее содержание клетки, он необходим в большем количестве, чем любой питательный элемент. При внесении 150 и 200 т/га свиного навоза установлено самое высокое содержание общего азота.

Количество жира в зерне пшеницы яровой очень невелико (около 1,5-2\%). Содержание сырого жира в варианте с дозой внесения 200 т/га оказалось самым высоким $-1,45 \%$.

Пищевая клетчатка, которая содержится в растительных продуктах с низким или очень низким содержанием сахара, обычно объединяется с другими питательными веществами. Минимальное содержание сырой клетчатки отмечено в варианте 150 и 200 т/га, а максимальное на контрольном варианте.

Все эти показатели являются важными для определения качества зерна пшеницы яровой.

По большинству показателей качества самым лучшим вариантом является доза внесения жидкого свиного навоза 200 т/га.

\begin{tabular}{|c|c|c|c|c|c|}
\hline & & & \multirow{5}{*}{$-1+2$} & \multirow{5}{*}{ - } & \\
\hline & & & & & \multirow[b]{5}{*}{ клетчатка, т/га } \\
\hline & & & & & \\
\hline & & & & & \\
\hline & & & & & \\
\hline \multicolumn{2}{|c|}{ 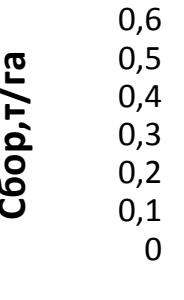 } & протеин, т/га & азот, т/га & жир, т/га & \\
\hline \multicolumn{2}{|c|}{ контроль } & 0,35 & 0,05 & 0,04 & 0,08 \\
\hline \multicolumn{2}{|c|}{50 т/га } & 0,38 & 0,06 & 0,05 & 0,09 \\
\hline \multicolumn{2}{|c|}{100 т/га } & 0,44 & 0,07 & 0,05 & 0,1 \\
\hline \multicolumn{2}{|c|}{150 т/га } & 0,48 & 0,08 & 0,05 & 0,1 \\
\hline \multicolumn{2}{|c|}{200 т/га } & 0,47 & 0,08 & 0,06 & 0,11 \\
\hline \multicolumn{2}{|c|}{ — 250 т/га } & 0,45 & 0,07 & 0,05 & 0,11 \\
\hline
\end{tabular}

Показатели качества

Рисунок 1 - Влияние доз внесения жидкой фракции свиного навоза на качество зерна пшеницы яровой 
На рисунке 1 мы видим, что одни из самых высоких значений по сбору азота, жира и клетчатки занимает вариант с дозой внесения 200 т/га, по сбору протеина и азота - вариант с дозой внесения 150 т/га. По сбору клетчатки так же высокое значение мы можем наблюдать и на варианте с дозой внесения 250 т/га жидкого свиного навоза.

За период исследования мы выявили влияние жидкой фракции свиного навоза на урожайность и качество зерна яровой пшеницы:

1) внесение жидкой фракции свиного навоза в объеме 200 т/га является лучшим вариантом в опыте, т.к. на нем была получена максимальная урожайность 4,97 т/га (прибавка по контролю составила - 1,47 т/га).

2) по большинству показателей качества зерна пшеницы яровой (содержание общего азота, сырого жира и сырой клетчатки) лучшим вариантом оказалась доза внесения жидкой фракции свиного навоза в объеме 200 т/га. 


\section{Литература}

1. Мерзлая Г.Е. Использование свиного навоза для удобрения сельскохозяйственных культур / Г.Е. Мерзлая, И.В. Щеголева, М.В. Леонов // Перспективное свиноводство: Теория и практика,2012. - №6. - 7$10 \mathrm{c}$.

2. Мерзлая Г.Е. Агроэкологические основы и технологии использования бесподстилочного навоза. / Мерзлая Г.Е. Новиков М.Н., Еськов А.И., Тарасов С.И. - М.: РАСХН, ВНИПТИОУ, 2006. - 463 с.

3. Семенова П.Я. Бесподстилочный навоз и его использование для удобрения/ П.Я. Семенова - М.: Колос, 1987. - 239 с.

4. Справочная книга по производству и применению органических удобрений / Владимир: РАСХН, ВНИПТИОУ - 2001. - 495 с. 